\title{
PENGARUH FAKTOR MOTIVASI KERJA DITINJAU DARI ASPEK FINANSIAL, LINGKUNGAN KERJA DAN PENGHARGAAN TERHADAP KINERJA PEGAWAI BIRO KEPEGAWAIAN SEKRETARIAT DAERAH PROVINSI KALIMANTAN SELATAN \\ "Mahfuzil Anwar"
}

\author{
ABSTRACTION
}

\begin{abstract}
INFLUENCE FACTORS WORK MOTIVATION VIEWED FROM FINANCIAL ASPECTS, ENVIRONMENTAL WORKING ON THE PERFORMANCE OF EMPLOYEES AND AWARDS SECRETARIAT STAFFING AGENCIES SOUTH KALIMANTAN PROVINCE
\end{abstract}

This study aims to obtain empirical evidence about the influence of motivational factors through the financial aspects, Work Environment and employee performance appraisals, the Civil Service Bureau of the Regional Secretariat of South Kalimantan Province.

The hypothesis put forward is a hypothesis I, Simultaneously Finance, Working Environment Award and affect the performance of employees in the Civil Service Bureau of the Regional Secretariat of South Kalimantan Province. Hypothesis II partial financial aspect is more dominant influence on the performance of employees in the Civil Service Bureau of the Regional Secretariat of South Kalimantan Province.

Through a questionnaire submitted to the respondent on the financial aspects with 20 items of questions, aspects of the work environment with 11 items of questions, and aspects of the awards with 9 items of questions, with three alternative answers $a, b$ and $c$ with a score of 3.2, and 1. The questionnaire performance with 16 items of questions and respondents as many as 102 people.

The results showed that the hypothesis I stating together the financial aspects, work environment and rewards affect the performance of employees at the Civil Service Bureau of the Regional Secretariat of South Kalimantan Province, is acceptable.

Hypothesis II stating financial has more dominant influence on the performance of employees in the Civil Service Bureau of the Regional Secretariat of South Kalimantan Province convicted.

Keywords: Finance, working environment, and Performance Award

\section{ABSTRAKSI}

Penelitian ini bertujuan untuk mendapatkan bukti empiris tentang pengaruh faktor motivasi melalui aspek Finansial, Lingkungan Kerja dan Penghargaan terhadap kinerja pegawai pada Biro Kepegawaian Sekretariat Daerah Provinsi Kalimantan Selatan.

Hipotesis yang dikemukakan adalah Hipotesis I, Secara simultan Finansial, Lingkungan Kerja dan Penghargaan berpengaruh terhadap kinerja pegawai pada Biro Kepegawaian Sekretariat Daerah Provinsi Kalimantan Selatan. Hipotesis II secara parsial aspek finansial lebih dominan berpengaruh terhadap kinerja pegawai pada Biro Kepegawaian Sekretariat Daerah Provinsi Kalimantan Selatan.

Melalui kuesioner yang diajukan kepada responden pada aspek finansial dengan 20 item pertanyaan, aspek lingkungan kerja dengan 11 item pertanyaan, dan aspek penghargaan dengan 9 item pertanyaan, dengan tiga alternative jawaban a,b dan c dengan skor 3,2, dan 1 . Adapun kuesioner kinerja dengan 16 item pertanyaan serta responden sebanyak 102 orang. 
Hasil penelitian menunjukkan bahwa Hipotesis I yang menyatakan secara bersamasama aspek financial, lingkungan kerja serta penghargaan berpengaruh terhadap kinerja pegawai pada Biro Kepegawaian Sekretariat Daerah Provinsi Kalimantan Selatan, dapat diterima.

Hipotesis II yang menyatakan financial mempunyai pengaruh yang lebih dominan terhadap kinerja pegawai pada Biro Kepegawaian Sekretariat Daerah Provinsi Kalimantan Selatan dinyatakan terbukti.

Kata Kunci : Finansial, Lingkungan kerja, Penghargaan dan Kinerja

\section{BAB I \\ PENDAHULUAN}

Pemanfaatan kemampuan pegawai dengan optimal dapat dilakukan jika mampu menyatukan pandangan, sifat, dan karakter yang berbeda-beda dari setiap pegawai pada suatu tujuan, yaitu tujuan organisasi. Berkaitan dengan hal itu, tugas seorang pimpinan organisasi adalah memotivasi para pegawainya agar bekerja sesuai dengan upaya pencapaian tujuan organisasi. Kemampuan dalam memotivasi, mempengaruhi, mengarahkan, dan berkomunikasi dengan para pegawai akan menentukan sejauh mana efektivitas leadership dari seorang pimpinan organisasi.

Para pegawai yang bekerja dengan motivasi tinggi merupakan harapan setiap organisasi. Pegawai yang memiliki motivasi hanya untuk bekerja saja tidak sama dengan pegawai yang bekerja dengan motivasi yang tinggi. Pegawai yang memiliki motivasi untuk bekerja pada umumnya beranggapan bahwa bekerja hanya karena hanya memenuhi kebutuhan yang vital bagi diri dan keluarganya. Hal inilah yang disebut dengan motivasi eksternal (As'ad, 1991). Pegawai dengan perilaku seperti ini tidak termotivasi untuk bekerja semaksimal mungkin. Sedangkan pegawai yang bekerja dengan motivasi yang tinggi, sebagaimana yang dibutuhkan oleh setiap organisasi, adalah pegawai yang merasa senang dalam melakukan pekerjaannya dan mendapat kepuasan dari pekerjaannya tersebut.

Dengan terciptanya kepuasan kerja pada diri seorang pegawai maka diharapkan akan terjadi peningkatan mutu pelayanan, karena bila pegawai tersebut merasa puas dan senang dalam bekerja selanjutnya diharapkan akan dapat melakukan tugasnya dengan baik dan tulus dalam menjalankan apa yang menjadi kewajibannya. Selain itu, kepuasan kerja juga akan membawa dampak pada rendahnya turnover, absensi, keterlambatan kerja, dan waktu-waktu luang yang ada, serta meningkatkan kinerja karyawan.

Berbagai upaya dalam meningkatkan motivasi kerja pegawai Biro Kepegawaian Sekda Provinsi Kalimantan Selatan dilihat dari aspek finansial telah dilakukan oleh unsur pimpinan, di antaranya dengan memberikan berbagai insentif atau perangsang sebagai pendapatan lain di luar gaji, seperti uang lembur, bantuan uang makan, bantuan uang minum, dan uang perangsang sebagai pendapatan lain di luar gaji. Selain upaya meningkatkan tambahan finansial, guna mendorong serta menambah semangat kerja para pegawai telah dilakukan terhadap lingkungan kerja, baik berupa penggantian dan perbaikan terhadap peralatan dan perlengkapan kerja seperti meja, kursi, peralatan komputer, serta pemasangan alat penyejuk udara (AC) di segenap ruangan. Pemilihan dan penetapan pegawai yang paling berprestasi, pelayanan kenaikan pangkat dan kenaikan gaji berkala yang terus menerus diperbaiki dan ditingkatkan untuk memberikan kepuasan pada para pegawai, serta pemberian penghargaan terhadap pegawai dengan masa kerja tertentu, merupakan beberapa bentuk penghargaan yang diberikan untuk mendorong semangat kerja pegawai. Berbagai upaya yang dilakukan oleh unsur pimpinan tersebut tak lain dimaksudkan untuk 
memacu motivasi kerja serta meningkatkan produktivitas sekerja pegawai kerja pegawai.

Bertolak dari uraian di atas, penelitian ini bermaksud mengkaji sejauh pengaruh faktor-faktor motivasi terhadap kinerja pegawai dalam suatu organisasi, khususnya organisasi pemerintahan. Kajian ini selanjutnya akan diwujudkan dalam bentuk penelitian dengan judul: "Pengaruh Faktor Motivasi Kerja Ditinjau dari Aspek Finansial, Lingkungan Kerja, dan Penghargaan Terhadap Kinerja Pegawai Biro Kepegawaian Sekretariat Daerah Provinsi Kalimantan Selatan".

Rumusan Masalah ; a. Apakah aspek finansial, lingkungan kerja, dan penghargaan sebagai faktor motivasi kerja berpengaruh terhadap kinerja pegawai Biro Kepegawaian Sekretariat Daerah Provinsi Kalimantan Selatan? b. Di antara faktor motivasi kerja tersebut, yaitu aspek finansial, lingkungan kerja, dan penghargaan, manakah yang mempunyai pengaruh paling dominan terhadap kinerja pegawai Biro Kepegawaian Sekretariat Daerah Provinsi Kalimantan Selatan?

Tujuan Penelitian ; a. Menganalisis pengaruh aspek finansial, lingkungan kerja, dan penghargaan sebagai faktor motivasi kerja terhadap kinerja pegawai Biro Kepegawaian Sekretariat Daerah Propinsi Kalimantan Selatan. b. Menentukan manakah di antara faktor motivasi kerja tersebut yang paling dominan berpengaruh terhadap Kinerja pegawai Biro Kepegawaian Sekretariat Daerah Propinsi Kalimantan Selatan.

Tujuan Penelitian ; a. Dari sisi praktis, hasil penelitian ini diharapkan dapat digunakan sebagai bahan pertimbangan bagi Biro Kepegawaian Sekretariat Daerah Provinsi Kalimantan Selatan dalam menetapkan strategi dan kebijakan di bidang pengembangan sumber daya manusia pada masa-masa mendatang, khususnya yang berkaitan dengan upaya untuk meningkatkan motivasi kerja pegawai di mana tentunya sangat erat kaitannya dengan upaya peningkatan kinerja organisasi. b. Sedangkan dari sisi teoritis, penelitian ini diharapkan daerah menambah atau memperkaya suatu komplikasi tentang berbagai macam faktor yang mempengaruhi kinerja di kalangan pegawai negeri sipil. c. Pada sisi lain kegiatan penelitian ini merupakan kesempatan berharga untuk mengaplikasikan konsep, pendekatan, ataupun teori-teori yang ada dengan kondisi yang senyatanya ada di tempat kerja, sekaligus sebagai tambahan wawasan ilmu pengetahuan.

\section{BAB 2 \\ LANDASAN TEORI \\ 2.1. Motivasi Kerja}

Seorang pegawai dalam melaksanakan pekerjaan yang dibebankan kepadanya mungkin dapat dikerjakan dengan baik mungkin pula tidak. Bila seorang pegawai telah menjalankan tugasnya sedangkan produktivitas kerjanya tidak sesuai dengan yang diharapkan atau diinginkan, maka perlu diketahui apa sebab-sebabnya. Mungkin pengawai yang bersangkutan memang tidak mampu menyelesaikan pekerjaan yang ditugaskan, tapi bisa juga karena dia tidak mempunyai dorongan atau motivasi untuk bekerja dengan baik.

Oleh karena itu, menjadi salah satu tugas pimpinan suatu unit kerja atau satuan kerja untuk memberikan dorongan atau motivasi kepada pegawai atau bawahannya agar bekerja sesuai dengan apa yang diharapkan. Berkaitan dengan hal tersebut, maka pengetahuan tentang motivasi perlu diketahui oleh setiap pimpinan dan bahkan setiap orang yang bekerja dengan bantuan orang lain.

Motivasi dapat dijelaskan sebagai suatu dasar pendorong atau perangsang yang menyebabkan orang akan berbuat sesuatu dan motivasi ini merupakan penuntun kekuatan yang menggerakkan manusia untuk bertingkah laku untuk mencapai tujuan tertentu. Selain itu, motivasi merupakan suatu proses untuk mencoba mempengaruhi agar seseorang dapat melakukan sesuatu yang kita 
inginkan (Handoko dalam Heidjrahman dan Suad Husnan, (2003). Sementara Gibson (1998) menyatakan bahwa motivasi adalah kekuatan dalam diri seseorang yang mampu mendorongnya melakukan sesuatu yang menimbulkan dan mengarahkan perilaku.

Berdasarkan ulasan ringkas di atas, maka pengertian motivasi yang digunakan dalam penelitian ini adalah kebutuhan-kebutuhan dalam diri pribadi seorang yang mendorong keinginan individu menimbulkan semangat kerja dan mendorong produktivitas kerja.

\subsection{Pengertian dan Penilaian Kinerja}

Sebagai suatu sistem, organisasi pemerintahan maupun organisasi bisnis tidak dapat lepas dari lingkungannya baik yang bersifat internal maupun eksternal. Lingkungan yang melingkupi dan mempengaruhi jalannya organisasi, sifatnya selalu berubah dan berkembang sesuai dengan tuntutan internal dan tuntutan eksternal tersebut. Memenuhi tuntutan lingkungan berarti dapat memanfaatkan kesempatan dan mengatasi tantangan/ancaman dari lingkungan yang kompleks. Oleh karena itu sebagai konsekuensinya sebuah organisasi harus melakukan berbagai kegiatan dalam menghadapi atau memenuhi tuntutan lingkungan tersebut.

Ditetapkan sistem penilaian kinerja pegawai di Biro Kepegawaian Sekretariat Daerah Provinsi Kalimantan Selatan mempunyai tujuan untuk meningkatkan produktivitas dan efektivitas kerja pegawai yang tentunya bersumber dari tujuan sistem penilaian di atas.

Penilaian kinerja mengandung manfaat/kegunaan yang dapat dirinci sebagai berikut:

1. Perbaikan prestasi kerja.

2. Penyesuaian-penyesuaian kompensasi

3. Keputusan-keputusan penempatan

4. Kebutuhan-kebutuhan latihan dan pengembangan

5. Perencanaan dan pengembangan karier
6. Penyimpangan-penyimpangan proses staffing.

7. Ketidakakuratan informasi

8. Kesalahan-kesalahan desain pekerjaan

9. Kesempatan kerja yang adil

10. Tantangan-tantangan eksternal (Dharma, 1995:23)

Menurut Flippo (1984) bahwa agar seseorang mencapai kinerja yang tinggi tergantung pada kerja sama, kepribadian, kepandaian, kepemimpinan, keselamatan, pengetahuan tentang pekerjaan, kehadiran, kesetiaan, ketangguhan, dan inisiatif. Sementara menurut Robins (1997) bahwa kinerja karyawan merupakan fungsi dari interaksi antara kemampuan dan motivasi. Di samping motivasi perlu juga dipertimbangkan kemampuan yang mencakup kecerdasan dan keterampilan untuk menjelaskan dan menilai kinerja karyawan. Kesempatan untuk berkinerja perlu pula ditambahkan meskipun seorang karyawan mungkin bersedia dan mampu.

Bila seorang pegawai dalam penilaian menunjukkan tidak berkinerja akan tetapi sebenarnya dia mempunyai potensi, ada kemungkinan lingkungan kerjanya yang tidak mendukung. Perlu diketahui apakah pegawai tersebut telah mempunyai peralatan kerja yang mendukung, bahan dan perbekalan yang memadai, kondisi bekerja yang menguntungkan, cukup informasi untuk mengambil keputusan yang berkaitan dengan pekerjaannya, waktu yang memadai untuk melakukan pekerjaan dengan baik, dan lain-lain. Jika karyawan tersebut tidak mendapatkan hal tersebut maka secara langsung dengan kinerja pegawai, seorang manajer perlu pula menetapkan tujuan kinerja.

Menurut Simamora (1997) maksud penetapan tujuan kinerja adalah untuk menyusun sasaran yang berguna tidak hanya bagi evaluasi kinerja pada akhir periode, tetapi juga untuk mengelola proses kerja selama periode tersebut. Ada tiga alasan mengapa penentuan sasaran mempengaruhi kinerja:

1. Penentuan sasaran mempunyai dampak 
mengarahkan, memfokuskan aktivitas ke arah tertentu dari pada lainnya.

2. Sasaran yang telah diterima maka orang cenderung mengarahkan upaya secara proporsional terhadap kesulitan.

3. Sasaran yang sukar akan membuahkan kekuatan dibandingkan sasaran yang ringan.

Sedang menurut Gerry Dessler (1995) alasan perlunya menilai kinerja karyawan yaitu:

1. Menyediakan informasi sebagai dasar pengambilan keputusan tentang promosi dan gaji.

2. Menyediakan kesempatan bagi karyawan untuk bersama-sama meninjau perilaku karyawan berkaitan dengan pekerjaannya.

Dengan demikian kinerja adalah hasil yang dicapai oleh seseorang dalam bidang pekerjaannya menurut kriteria tertentu yang berlaku untuk suatu pekerjaan tertentu dan dievaluasi oleh orang-orang tertentu. Di dalam menilai kinerja pegawai tidak hanya menilai hasil secara fisik, tetapi juga pelaksanaan pekerjaan secara keseluruhan yang menyangkut berbagai aspek seperti kemampuan kerja, kerajinan, disiplin, hubungan kerja, atau hal-hal khusus sesuai dengan bidang dan tingkatan pekerjaan (Soeprihanto, 1996:2).

Menurut Robbins (1997) bahwa pada hakikatnya penilai terhadap individu merupakan hasil kerja yang diharapkan berupa suatu kinerja optimal. Dalam penelitian ini, penilaian kinerja mencakup beberapa hal antara lain:

1. Kerja sama.

2. Kualitas pekerjaan.

3. Kemampuan teknis.

4. Daya tangkap instruksi

5. Semangat

6. Daya tahan kerja

7. Kedisiplinan

\subsection{Pengukuran Kinerja}

Untuk mengetahui sampai sejauh mana tingkat hasil pelaksanaan pekerjaan pegawai, maka perlu diadakan suatu evaluasi terhadap hasil kerjanya. Cascio (1992) menguraikan beberapa hal yang berkaitan dengan penilaian kinerja antara lain:

1. Kinerja menunjukkan penyelesaian tugas yang telah dilakukan oleh karyawan.

2. Penilaian kinerja adalah uraian sistematik tentang kekuatan dan kelemahan berkenaan dengan pekerjaan tersebut dari seseorang atau kelompok.

3. Periode penilaian kinerja adalah rentang waktu di mana seseorang diamati prestasi kerjanya.

Penilaian kinerja (performance appraisal) memadukan peranan yang sangat penting dalam meningkatkan motivasi kerja. Penilaian kinerja merupakan upaya membandingkan prestasi aktual pegawai dengan prestasi kerja yang diharapkan dari pegawai tersebut. Perbedaan penilaian kinerja antara orang yang satu dengan lainnya dalam satu situasi kerja adalah karena perbedaan karakteristik dari individu. Demikian pula orang yang sama dapat menghasilkan performance kerja yang berbeda dalam situasi kerja yang berbeda tentunya dalam penilaian kinerja tetap mempertimbangkan berbagai keadaan dan perkembangan yang mempengaruhi kinerja tersebut.

Penilaian kinerja adalah alat yang berfaedah tidak hanya untuk mengevaluasi kerja pegawai, tetapi juga untuk mengembangkan dan memotivasi kalangan pegawai. Dalam penilaian kinerja dinilai kontribusi pegawai kepada organisasi selama periode waktu tertentu. Umpan balik kinerja memungkinkan pegawai mengetahui seberapa baik mereka bekerja jika dibandingkan dengan standar organisasi. Untuk menentukan ukuran tentang sukses dalam suatu pekerjaan amatlah sulit, karena sering kali pekerjaan itu begitu kompleks sehingga sulit untuk menentukan ukuran output yang pasti. Kondisi tersebut terutama terdapat pada jabatan-jabatan yang bersifat administratif. Selanjutnya seperti yang dikemukakan 
oleh Maier (1965) bahwa yang umum dianggap sebagai kriteria antara lain adalah: kualitas, kuantitas, waktu yang dipakai, jabatan yang diduduki, tingkat kehadiran, dan keselamatan dalam menjalankan tugas.

\subsection{Kerangka Konseptual}

Berdasarkan uraian pada latar belakang, tinjauan pustaka, serta pemahaman terhadap model dan teori tentang motivasi dan prestasi kerja sebagaimana telah diuraikan sebelumnya, maka kerangka konseptual dalam penelitian ini digambarkan sebagai berikut:

GAMBAR 1

KERANGKA KONSEPTUAL

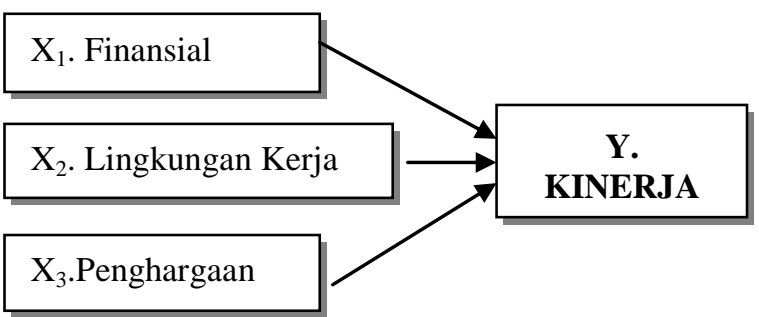

\subsection{Hipotesis}

Berdasarkan kerangka konseptual yang telah dikemukakan, maka dalam penelitian ini hipotesis yang akan diuji yaitu:

1. Aspek finansial, lingkungan kerja, dan penghargaan (sebagai faktor motivasi kerja), secara bersama-sama berpengaruh terhadap kinerja pegawai Biro Kepegawaian Sekretariat Daerah Propinsi Kalimantan Selatan.

2. Secara parsial aspek finansial merupakan faktor yang paling dominan dalam mempengaruhi kinerja pegawai Biro Kepegawaian Sekretariat Daerah Provinsi Kalimantan Selatan.

\section{BAB 3 METODE PENELITIAN}

\subsection{Rancangan Penelitian}

Penelitian ini merupakan penelitian penjelasan (explanatory atau confirmatory research) yang merupakan penelitian yang menyoroti hubungan antara variabelvariabel penelitian dan menguji hipotesis yang telah dirumuskan sebelumnya (Masri Singarimbun dan Sofian Effendi, 1987). Berdasarkan variabel-variabel yang hendak diteliti, penelitian ini bermaksud menganalisis Pengaruh faktor motivasi kerja ditinjau dari aspek finansial, lingkungan kerja dan penghargaan terhadap kinerja pegawai Biro Kepegawaian Sekretariat Daerah Provinsi Kalimantan Selatan.

\subsection{Rancangan Penelitian}

Populasi merupakan wilayah generalisasi yang terdiri atas objek/subjek yang mempunyai kualitas dan karakteristik tertentu yang ditetapkan dalam penelitian untuk dipelajari dan kemudian ditarik kesimpulan (Sugiyono, 2003:72).

Penelitian ini mengambil populasi Pegawai Negeri Sipil (PNS) pada Biro Kepegawaian Sekretariat Daerah Provinsi Kalimantan Selatan yang berkedudukan sebagai staf, dimana pada saat penelitian ini dilakukan berjumlah 138 orang. Untuk menentukan besarnya sampel pada penelitian survey maka digunakan rumus sebagai berikut (Zainuddin, 2000):

$$
\begin{aligned}
\mathrm{n} & =\frac{\mathrm{N} \times \mathrm{Z}_{1 / 2 \alpha}{ }^{2} \times \mathrm{p} \times \mathrm{g}}{(\mathrm{N}-1) \mathrm{d}^{2}+\mathrm{Z}_{1 / 2 \varepsilon}{ }^{2} \times \mathrm{p} \mathrm{x} \mathrm{g}} \\
& =\frac{138 \times(1,96)^{2} \times 0,5 \times 0,5}{137(0,05)^{2}+(1,96)^{2} \times 0,5 \times 0,5} \\
& =101,7=102
\end{aligned}
$$

Dengan demikian besar sampel yang digunakan adalah 102.

Sedangkan teknik pengambilan sampel dilakukan dengan Acak Sederhana (Simple Random Sampling), yaitu sampel yang diambil sedemikian rupa sehingga tiap unit analisis atau satuan elementer dari populasi punya kesempatan sama untuk dipilih menjadi sampel dengan asumsi sampel mempunyai keragaman yang sama (homogen).

\subsection{Variabel Penelitian}

Sebagaimana yang terlihat dalam konsep judul penelitian ini, maka tersirat 2 (dua) variabel utama yang digunakan 
dalam penelitian ini, yaitu:

a. Sebagai variabel independen atau variabel bebas (X) adalah faktorfaktor motivasi kerja yang terdiri dari: $\mathrm{X}_{1}=$ Faktor Finansial $\mathrm{X}_{2}=$ Faktor Lingkungan Kerja $\mathrm{X}_{3}=$ Faktor Penghargaan

b. Sebagai variabel dependen atau variabel terikat (Y) adalah Kinerja Pegawai.

\subsection{Definisi Operasional}

Definisi operasi dalam penelitian ini adalah sebagaimana terurai berikut:

1. Faktor Finansial $\left(\mathbf{X}_{1}\right)$. Dalam penelitian ini, yang dimaksud dengan faktor finansial adalah gaji yang diterima oleh pegawai ditambah penghasilan lain yang sah. Adapun indikator faktor finansial misalnya berupa:

a. Gaji yang diterima termasuk tunjangan (anak, istri/suami).

b. Upah lembur, dan penghasilan lain yang sah (uang bantuan, perangsang)

c. Kemakmuran pegawai dari segi ekonomi setelah bekerja.

Daftar pertanyaan yang diajukan adalah yang berkaitan dengan variabel finansial $\left(\mathrm{X}_{1}\right)$ sebanyak 20 item.

2. Faktor Lingkungan Kerja $\left(\mathbf{X}_{2}\right)$. Dalam penelitian ini, yang dimaksud dengan faktor kerja adalah kondisikondisi kerja berupa keadaan lingkungan fisik dan sesuai di tempat kerja, beserta dengan fasilitas-fasilitas yang ada. Indikator yang digunakan sebagai unsur faktor lingkungan kerja di antaranya adalah:

a. Peralatan kerja

b. Ruangan kerja

c. Sarana transportasi

d. Hubungan sosial

e. Sarana kesehatan

Daftar pertanyaan yang diajukan adalah yang berkaitan dengan variabel lingkungan kerja $\left(\mathrm{X}_{2}\right)$ sebanyak 11 item.

\section{Faktor Penghargaan $\left(\mathrm{X}_{3}\right)$.}

Dalam penelitian ini, yang dimaksud dengan faktor penghargaan adalah penghormatan atau hadiah yang diberikan kepada seorang pegawai atas hasil/prestasinya. Di mana semakin baik organisasi memberikan penghargaan yang berkaitan dengan kepuasan kerja dan kesejahteraan lainnya, maka kinerja pegawai tersebut akan semakin baik pula. Adapun indikator dari faktor penghargaan tersebut berupa:

a. Kesempatan mengikuti diklat struktural.

b. Kesempatan untuk mendapatkan kenaikan pangkat

c. Mendapatkan promosi (jabatan, dan sebagainya)

d. Mendapatkan piagam penghargaan atas prestasi kerjanya

Daftar pertanyaan yang diajukan adalah yang berkaitan dengan variabel penghargaan $\left(\mathrm{X}_{3}\right)$ terdiri atas 9 item.

4. Kinerja (Y) adalah tingkat sejauh mana keberhasilan atau efektivitas pegawai dalam melaksanakan tugas dan tanggung jawab untuk mencapai tujuan sesuai dengan standar yang telah ditetapkan organisasinya, baik secara kualitas maupun kuantitas. Indikator dari penilaian prestasi kerja misalnya:

a. Kualitas kerja

b. Kuantitas kerja

c. Ketepatan waktu

d. Efektivitas kerja

e. Kemandirian

f. Hubungan interpretasi

Daftar pertanyaan yang diajukan adalah yang berkaitan dengan variabel Kinerja Pegawai (Y) sebagai dependent variable dengan 16 item pertanyaan.

Seluruh butir-butir pertanyaan/questionaire dalam penelitian ini terdiri dari tiga alternatif jawaban. Data jawaban para responden tersebut diberi skor dengan menggunakan sistem skala 1-3. Dalam hal ini ada 3 klasifikasi 
jawaban yang diberikan dengan kemungkinan pemberian skor nilai sebagai berikut:

1. Jawaban (A) diberi nilai 3

2. Jawaban (B) diberi nilai 2

3. Jawaban $(\mathrm{C})$ diberi nilai 1

\subsection{Instrumen Penelitian}

Instrumen penelitian yang digunakan untuk mengumpulkan data penelitian ini adalah berupa daftar pertanyaan/questionnaire, data dokumen/ arsip.

\subsection{Metode Pengumpulan Data}

Metode pengumpulan data yang dilakukan pada penelitian ini adalah sebagai berikut:

1. Melakukan tanya jawab secara langsung pada pihak-pihak yang berkompeten di Biro Kepegawaian Sekretariat Daerah Provinsi Kalimantan Selatan yang dijadikan objek penelitian.

2. Menyebarkan questionnaire kepada pegawai untuk kemudian mereka mengisi jawaban atas pertanyaan tertulis yang ada dalam kuesioner.

3. Melaksanakan pengamatan langsung atas gejala-gejala yang ada dan berkaitan dengan permasalahan yang diteliti di lokasi penelitian.

4. Melakukan pencatatan atas beberapa dokumen dan arsip pada Biro Kepegawaian Sekretariat Daerah Provinsi Kalimantan Selatan yang telah dipublikasikan.

\subsection{Uji Validitas dan Reliabilitas Instrumen}

Uji validitas untuk menguji kuesioner yang digunakan untuk mendapatkan data yang valid. Valid berarti kuesioner tersebut dapat digunakan untuk mengukur apa yang seharusnya diukur. Uji validitas dalam penelitian ini menggunakan metode item total corellation (perhitungan statistik SPSS) Koefisien korelasi masing-masing item kemudian dibandingkan dengan $r$ kritis yang ada pada tabel kritis products momen sesuai dengan derajat kebebasannya dan tingkat signifikannya. Bila koefisien korelasi lebih besar dari nilai kritis, maka suatu pernyataan dianggap valid. Sebaliknya bila koefisien korelasi lebih kecil dari nilai kritisnya, maka suatu pernyataan dianggap tidak valid. Menurut Masrun (1979) bahwa bilamana koefisien korelasi antara skor suatu indikator dengan skor total seluruh indikator lebih besar 0,3 ( $\mathrm{r}>0,3)$ maka instrumen tersebut dianggap valid.

Sedangkan uji reliabilitas menggunakan metode Alpha-Cronbach dengan rumus:

$$
\alpha=\frac{\mathrm{n}}{\mathrm{n}-1}\left(1-\frac{\sum \mathrm{V}_{1}}{\mathrm{~V}_{\mathrm{t}}}\right)
$$

dimana :

$$
\begin{array}{lll}
\mathrm{n} & \text { jumlah butir } \\
\mathrm{V}_{\mathrm{i}} & : \text { varians item } \\
\mathrm{V}_{\mathrm{t}} & : \text { varians total }
\end{array}
$$

Menurut Malhotra (1996) suatu instrumen (keseluruhan indikator) dianggap sudah reliabilitas jika angka alpha yang diperoleh lebih besar dari 0,6. Uji validitas dan reliabilitas ini dilakukan sebelum penelitian dilakukan dengan mengujikan pada 30 responden kepada staf di Bagian Biro Kepegawaian selain yang dijadikan sebagai sampel.

\subsection{Teknik Analisis Data}

Untuk menganalisis data penelitian ini digunakan analisis data deskriptif dan uji regresi linier berganda. Analisis deskriptif digunakan untuk memberikan deskripsi mengenai subjek penelitian berdasarkan data yang diperoleh, disajikan dalam bentuk tabel frekuensi dan persentase. Regresi digunakan untuk mengetahui atau menguji apakah ada pengaruh yang positif atau tidak antara faktor-faktor motivasi kerja yang meliputi aspek finansial, lingkungan kerja, dan penghargaan dengan kinerja pegawai.

Bentuk umum dari model yang akan digunakan adalah: 


$$
Y=\beta_{0}+\beta_{1} X_{1}+\beta_{2} X_{2}+\beta_{3} X_{3}+e
$$

dimana:

$$
\begin{aligned}
& \mathrm{Y}=\text { Kinerja } \\
& \beta_{0}=\text { nilai konstanta } \\
& \mathrm{X}_{1}=\text { Faktor finansial } \\
& \mathrm{X}_{2}=\text { Faktor lingkungan kerja } \\
& \mathrm{X}_{3}=\text { Faktor penghargaan }
\end{aligned}
$$

$\beta_{1}, \beta_{2}, \beta_{3}=$ slope $; \quad \mathrm{e}=$ kesalahan prediksi

Selanjutnya, diterima atau tidak diterimanya hipotesis yang diajukan dilakukan dengan uji $\mathrm{F}$ (F-test) secara simultan dan uji t (t-test) secara parsial.

\section{Pengujian hipotesis $I$}

Pembuktian kebenaran hipotesis I, menggunakan uji F (F-test) yaitu pengujian secara simultan atau bersamasama. Uji $F$ dilakukan dengan membandingkan $\mathrm{F}_{\text {hitung }}$ dengan $\mathrm{F}$ tabel pada $\alpha=0,05$. Kesimpulan diperoleh melalui hasil perhitungan sebagai berikut :

a. Signifikansi > 0,05, maka Ho ditolak dan Ha diterima, artinya variabel independennya secara simultan mempengaruhi variabel dependennya.

b. Signifikansi $\leq 0,05$, maka Ho diterima dan $\mathrm{Ha}$ ditolak, artinya variabel independennya secara simultan tidak mempengaruhi variabel dependennya.

Selanjutnya untuk melihat kemampuan variabel independen dalam menerangkan variabel dependen dapat diketahui dari besarnya koefisien determinasi berganda $\left(\mathrm{R}^{2}\right)$. Dengan kata lain, nilai $\mathrm{R}^{2}$ digunakan untuk mengukur besarnya sumbangan variabel independen terhadap variasi variabel dependennya. Jika $\mathrm{R}^{2}$ diperoleh dari hasil perhitungan semakin besar atau mendekati 1 maka dapat dikatakan bahwa sumbangan dari variabel independen terhadap variasi variabel dependen semakin besar. Ini berarti model yang digunakan semakin kuat untuk menerangkan variabel dependennya. Sebaliknya jika $\left(\mathrm{R}^{2}\right)$ semakin kecil atau mendekati 0 maka dapat dikatakan bahwa sumbangan dari variabel independen terhadap variasi variabel dependen semakin kecil. Hal ini berarti model yang digunakan semakin lemah untuk menerangkan variasi variabel dependennya. Secara umum dapat dikatakan bahwa besarnya koefisien determinasi berganda $\left(\mathrm{R}^{2}\right)$ berada di antara 0 dan 1 atau $0 \leq\left(\mathrm{R}^{2}\right) \leq 1$.

\section{Pengujian hipotesis II}

Untuk membuktikan hipotesis II, maka digunakan uji t (T-test) secara parsial yaitu dengan cara membandingkan $\mathrm{t}$ hitung dengan $\mathrm{t}$ tabel pada $\alpha=0,05$. Apabila hasil pengujian menunjukkan:

a. Signifikansi > tabel maka Ho ditolak dan Ha diterima. Artinya, variabel independen mempengaruhi secara signifikan terhadap variabel dependen.

b. Signifikansi $\leq \mathrm{t}$ tabel maka Ho diterima dan Ha ditolak. Artinya, variabel independen mempengaruhi variabel dependennya tetapi tidak signifikan.

Semakin besar $t_{\text {hitung }}$ suatu variabel independen menunjukkan semakin dominan variabel independen tersebut terhadap variabel dependennya.

\section{BAB 4 \\ HASIL PENELITIAN DAN PEMBAHASAN}

\subsection{Deskripsi Karakteristik Responden \\ a. Jenis Kelamin}

Data jenis kelamin responden pegawai Biro Kepegawaian

Sekretariat Daerah Provinsi Kalimantan Selatan seperti tampak pada tabel berikut : 
Tabel 4.1

Distribusi Jenis Kelamin

Responden PNS Biro Kepegawaian

Sekretariat Daerah Provinsi

Kalimantan Selatan

\begin{tabular}{|c|c|c|c|}
\hline No. & $\begin{array}{c}\text { Jenis } \\
\text { Kelamin }\end{array}$ & $\begin{array}{c}\text { Jumlah } \\
\text { (Orang } \\
\text { Pegawai) }\end{array}$ & $\begin{array}{c}\text { Persentase } \\
(\mathbf{\%})\end{array}$ \\
\hline 1. & Laki-laki & 62 & 61 \\
\hline 2. & Perempuan & 40 & 39 \\
\hline \multicolumn{2}{|c|}{ Jumlah } & $\mathbf{1 0 2}$ & $\mathbf{1 0 0}$ \\
\hline
\end{tabular}

Sumber : Biro Kepegawaian Sekda

Propinsi Kalimantan Selatan, 2015

Dari tabel di atas, pegawai dengan kinerja kategori jenis kelamin yang tersaji di atas, maka dapat diketahui bahwa responden yang berjenis kelamin laki-laki sebanyak 62 orang pegawai atau sebesar $61 \%$. Sedangkan pegawai perempuan (wanita) sebanyak 40 orang pegawai yang berarti sebesar 39\%. Dari data tersebut dapat diketahui dapat diketahui bahwa responden penelitian yang ada di Biro Kepegawaian Sekretariat Daerah Provinsi Kalimantan Selatan sebagian besar pegawai laki-laki (pria).

\section{b. Umur}

Data responden yang ada di Biro Kepegawaian Sekretariat Daerah Provinsi Kalimantan Selatan berdasarkan kategori umur dapat peneliti sajikan dalam tabel berikut ini

Tabel 4.2

Distribusi Umur Responden PNS Biro Kepegawaian Sekretariat Daerah Provinsi Kalimantan Selatan

\begin{tabular}{|c|c|c|c|}
\hline No. & Usia & $\begin{array}{c}\text { Jumlah } \\
\text { (Orang } \\
\text { Pegawai) }\end{array}$ & $\begin{array}{c}\text { Persentase } \\
(\%)\end{array}$ \\
\hline 1. & $\begin{array}{c}21-30 \\
\text { tahun }\end{array}$ & 7 & 7 \\
\hline 2. & $\begin{array}{c}31-40 \\
\text { tahun }\end{array}$ & 30 & 30 \\
\hline 3. & $41-50$ & 46 & 46 \\
\hline
\end{tabular}

\begin{tabular}{|c|c|c|c|}
\hline No. & Usia & $\begin{array}{c}\text { Jumlah } \\
\text { (Orang } \\
\text { Pegawai) }\end{array}$ & $\begin{array}{c}\text { Persentase } \\
(\mathbf{\%})\end{array}$ \\
\hline & tahun & & \\
\hline 4. & $>51$ tahun & 19 & 19 \\
\hline \multicolumn{2}{|r|}{ Jumlah } & $\mathbf{1 0 2}$ & $\mathbf{1 0 0}$ \\
\hline
\end{tabular}

Sumber : Biro Kepegawaian Sekda Propinsi Kalimantan Selatan, 2015

Dari tabel di atas pegawai di Biro Kepegawaian Sekretariat Daerah Provinsi Kalimantan Selatan berdasarkan umur, dapat diketahui bahwa pegawai yang paling banyak adalah pada kategori umur 41-50 sebanyak 46 orang (45\%). Sedangkan yang paing sedikit adalah pada kategori 21-30 tahun sebanyak 7 orang $(7 \%)$.

\section{c. Pendidikan}

Data responden yang ada di Biro Kepegawaian Sekretariat Daerah Provinsi Kalimantan Selatan berdasarkan tingkat pendidikan dapat peneliti sajikan dalam tabel berikut ini.

Tabel 4.3

Distribusi Tingkat Pendidikan Responden PNS Biro Kepegawaian Sekretariat Daerah Provinsi Kalimantan Selatan

\begin{tabular}{|c|l|c|c|}
\hline $\begin{array}{c}\text { No } \\
\cdot\end{array}$ & \multicolumn{1}{|c|}{$\begin{array}{c}\text { Tingkat } \\
\text { Pendidikan }\end{array}$} & $\begin{array}{c}\text { Jumlah } \\
\text { (Orang } \\
\text { Pegawai } \\
\text { ) }\end{array}$ & $\begin{array}{c}\text { Persentas } \\
\text { e (\%) }\end{array}$ \\
\hline 1. & SD & 1 & 1 \\
\hline 2. & SLTP & 2 & 2 \\
\hline 3. & SMU & 39 & 38 \\
\hline 4. & $\begin{array}{l}\text { Sarmud/Diplom } \\
\text { a }\end{array}$ & 2 & 2 \\
\hline 5 & S1 & 51 & 50 \\
\hline 6. & S2 & 7 & 7 \\
\hline 7. & S3 & 0 & 0 \\
\hline \multicolumn{2}{|l|}{ Jumlah } & $\mathbf{1 0 2}$ & $\mathbf{1 0 0}$ \\
\hline
\end{tabular}

Sumber : Biro Kepegawaian Sekda Propinsi Kalimantan Selatan, 2015

Dari tabel di atas pegawai di Biro Kepegawaian Sekretariat Daerah Provinsi Kalimantan Selatan berdasarkan tingkat pendidikan, dapat diketahui bahwa pegawai yang paling 
banyak adalah dengan tingkat pendidikan S1 yaitu dengan jumlah 51 orang pegawai atau sebesar $50 \%$. Kemudian diikuti oleh pegawai dengan tingkat pendidikan SLTA, yaitu sebanyak 39 orang pegawai atau sebesar 38\%. Sedangkan untuk tingkat pendidikan S2 sebanyak 7 orang pegawai yang berarti sebesar $7 \%$ dan untuk selanjutnya adalah untuk tingkat SLTP, Diploma sebanyak 2 orang pegawai atau sebesar $2 \%$ SD hanya 1 orang $(1 \%)$ dan tidak ada responden yang berpendidikan S3.

\section{d. Golongan/Ruang}

Komposisi pegawai dengan berdasarkan atas tingkat golongan dan ruang seperti yang terjadi dalam tabel berikut ini.

Tabel 4.4

Distribusi Golongan/Ruang Responden PNS Biro Kepegawaian Sekretariat Daerah Provinsi Kalimantan Selatan

\begin{tabular}{|c|c|c|c|}
\hline No. & $\begin{array}{c}\text { Tingkat } \\
\text { Golongan } \\
\text { Pegawai }\end{array}$ & $\begin{array}{c}\text { Jumlah } \\
\text { (Orang } \\
\text { Pegawai) }\end{array}$ & $\begin{array}{c}\text { Persentase } \\
(\%)\end{array}$ \\
\hline 1. & III/d & 10 & 10 \\
\hline 2. & III/c & 7 & 7 \\
\hline 3 & III/b & 41 & 41 \\
\hline 4 & III/a & 11 & 11 \\
\hline 5 & $\mathrm{II} / \mathrm{d}$ & 7 & 7 \\
\hline 6 & $\mathrm{II} / \mathrm{c}$ & 8 & 8 \\
\hline 7 & $\mathrm{II} / \mathrm{b}$ & 10 & 10 \\
\hline 8 & II/a & 3 & 3 \\
\hline 9 & $\mathrm{I} / \mathrm{d}$ & 2 & 2 \\
\hline 10 & $\mathrm{I} / \mathrm{c}$ & 2 & 2 \\
\hline 11 & $\mathrm{I} / \mathrm{b}$ & 1 & 1 \\
\hline \multicolumn{2}{|c|}{$\begin{array}{c}\text { Jumlah } \\
\text { Keseluruhan }\end{array}$} & 102 & 100 \\
\hline
\end{tabular}

Sumber : Biro Kepegawaian Sekda Propinsi Kalimantan Selatan, 2015

Dari tabel tentang distribusi berdasarkan golongan atau ruang di
Biro Kepegawaian Sekretariat Daerah Provinsi Kalimantan Selatan di atas menunjukkan bahwa komposisi golongan pegawai apabila ditinjau dari komposisinya relatif tidak seimbang karena jumlah pegawai terbanyak adalah pada golongan IIIb sebanyak 41 orang pegawai atau sebesar $40 \%$.

\subsection{Pengujian Validitas dan Reliabilitas Instrumen}

Dengan mendasarkan pada hasil angket/kuesioner, maka selanjutnya dilakukan tahapan-tahapan penelitian sebagai berikut:

\section{a. Uji Validitas}

Pengujian validitas kuesioner dilakukan terhadap 30 responden selain responden sebelum penelitian dilakukan.

Hasil pengujian selengkapnya dapat dilihat pada tabel di bawah ini:

Tabel 4.5

Hasil Uji Validitas pada Variabel Finansial

\begin{tabular}{|c|c|c|c|}
\hline $\begin{array}{c}\text { No. } \\
\text { Pertanyaa } \\
\text { n }\end{array}$ & $\begin{array}{c}\text { Korelas } \\
\text { i } \\
\text { Product } \\
\text { Momen } \\
\mathbf{t}\end{array}$ & $\begin{array}{c}\mathbf{r} \\
\text { Kriti } \\
\mathbf{s}\end{array}$ & $\begin{array}{c}\text { Keteranga } \\
\mathbf{n}\end{array}$ \\
\hline 1 & 0,3720 & 0,30 & Valid \\
\hline 2 & 0,4132 & 0,30 & Valid \\
\hline 3 & 0,4569 & 0,30 & Valid \\
\hline 4 & 0,5484 & 0,30 & Valid \\
\hline 5 & 0,3847 & 0,30 & Valid \\
\hline 6 & 0,3926 & 0,30 & Valid \\
\hline 7 & 0,3399 & 0,30 & Valid \\
\hline 8 & 0,3703 & 0,30 & Valid \\
\hline 9 & 0,5665 & 0,30 & Valid \\
\hline 10 & 0,6315 & 0,30 & Valid \\
\hline 11 & 0,5798 & 0,30 & Valid \\
\hline 12 & 0,5633 & 0,30 & Valid \\
\hline 13 & 0,6215 & 0,30 & Valid \\
\hline 14 & 0,4075 & 0,30 & Valid \\
\hline 15 & 0,6440 & 0,30 & Valid \\
\hline 16 & 0,5476 & 0,30 & Valid \\
\hline 17 & 0,4075 & 0,30 & Valid \\
\hline 18 & 0,5159 & 0,30 & Valid \\
\hline 19 & 0,4423 & 0,30 & Valid \\
\hline 20 & 0,5476 & 0,30 & Valid \\
\hline
\end{tabular}

Sumber : data diolah kembali, 2015

Dari tabel di atas terlihat bahwa 
seluruh item di variabel finansial adalah valid, sehingga dapat digunakan untuk penelitian selanjutnya. Sedangkan validitas variabel lingkungan dapat dilihat pada tabel berikut:

Tabel 4.6

Hasil Uji Validitas pada Variabel Lingkungan Kerja

\begin{tabular}{|c|c|c|c|}
\hline $\begin{array}{c}\text { No. } \\
\text { Pertanyaa } \\
\mathbf{n}\end{array}$ & $\begin{array}{c}\text { Korelas } \\
\mathbf{i} \\
\text { Product } \\
\text { Momen } \\
\mathbf{t}\end{array}$ & $\begin{array}{c}\mathbf{r} \\
\text { Kriti } \\
\mathbf{s}\end{array}$ & $\begin{array}{c}\text { Keteranga } \\
\mathbf{n}\end{array}$ \\
\hline 21 & 0,7517 & 0,30 & Valid \\
\hline 22 & 0,8148 & 0,30 & Valid \\
\hline 23 & 0,7988 & 0,30 & Valid \\
\hline 24 & 0,6813 & 0,30 & Valid \\
\hline 25 & 0,8430 & 0,30 & Valid \\
\hline 26 & 0,8015 & 0,30 & Valid \\
\hline 27 & 0,8960 & 0,30 & Valid \\
\hline 28 & 0,7879 & 0,30 & Valid \\
\hline 29 & 0,8159 & 0,30 & Valid \\
\hline 30 & 0,7681 & 0,30 & Valid \\
\hline
\end{tabular}

Sumber : data diolah kembali, 2015

Dari tabel tersebut dapat dilihat bahwa seluruh item di variabel lingkungan kerja adalah valid, sehingga dapat digunakan untuk penelitian selanjutnya. Sedangkan validitas variabel penghargaan dapat dilihat pada tabel berikut:

Tabel 4.7

Hasil Uji Validitas pada Variabel Penghargaan

\begin{tabular}{|c|c|c|c|}
\hline $\begin{array}{c}\text { No. } \\
\text { Pertanyaa } \\
\mathbf{n}\end{array}$ & $\begin{array}{c}\text { Korelas } \\
\mathbf{i} \\
\text { Product } \\
\text { Momen } \\
\mathbf{t}\end{array}$ & $\begin{array}{c}\mathbf{T} \\
\text { Kriti } \\
\mathbf{s}\end{array}$ & $\begin{array}{c}\text { Keteranga } \\
\mathbf{n}\end{array}$ \\
\hline 31 & 0,5789 & 0,30 & Valid \\
\hline 32 & 0,6146 & 0,30 & Valid \\
\hline 33 & 0,5242 & 0,30 & Valid \\
\hline 34 & 0,5475 & 0,30 & Valid \\
\hline 35 & 0,6651 & 0,30 & Valid \\
\hline 36 & 0,3422 & 0,30 & Valid \\
\hline 37 & 0,7627 & 0,30 & Valid \\
\hline 38 & 0,6763 & 0,30 & Valid \\
\hline 39 & 0,7601 & 0,30 & Valid \\
\hline 40 & 0,5555 & 0,30 & Valid \\
\hline
\end{tabular}

Sumber : data diolah kembali, 2015
Dari tabel di atas dapat dilihat bahwa seluruh item di variabel penghargaan adalah valid, sehingga dapat digunakan untuk penelitian selanjutnya. Sedangkan validitas variabel Kinerja dapat dilihat pada tabel berikut :

Tabel 4.8

Hasil Uji Validitas pada Variabel Kinerja

\begin{tabular}{|c|c|c|c|}
\hline $\begin{array}{c}\text { No. } \\
\text { Pertanyaan }\end{array}$ & $\begin{array}{c}\text { Korelasi } \\
\text { Product } \\
\text { Moment }\end{array}$ & $\begin{array}{c}\text { T } \\
\text { Kritis }\end{array}$ & Keterangan \\
\hline 41 & 0,5128 & 0,30 & Valid \\
\hline 42 & 0,5128 & 0,30 & Valid \\
\hline 43 & 0,5396 & 0,30 & Valid \\
\hline 44 & 0,5549 & 0,30 & Valid \\
\hline 45 & 0,3155 & 0,30 & Valid \\
\hline 46 & 0,4386 & 0,30 & Valid \\
\hline 47 & 0,3922 & 0,30 & Valid \\
\hline 48 & 0,3325 & 0,30 & Valid \\
\hline 49 & 0,3179 & 0,30 & Valid \\
\hline 50 & 0,3891 & 0,30 & Valid \\
\hline 51 & 0,4799 & 0,30 & Valid \\
\hline 52 & 0,5093 & 0,30 & Valid \\
\hline 53 & 0,5977 & 0,30 & Valid \\
\hline 54 & 0,5555 & 0,30 & Valid \\
\hline 55 & 0,5347 & 0,30 & Valid \\
\hline 56 & 0,5860 & 0,30 & Valid \\
\hline
\end{tabular}

Sumber : data diolah kembali, 2015

Dari tabel di atas dapat dilihat bahwa seluruh item variabel kinerja adalah valid, sehingga dapat digunakan untuk penelitian selanjutnya.

\section{b. Uji Reliabilitas}

Hasil pengujian reliabilitas dengan menggunakan alpha cronbach diperoleh hasil sebagai berikut:

Tabel 4.9

Hasil Uji Reliabilitas pada Variabel Penelitian

\begin{tabular}{|l|c|c|}
\hline \multicolumn{1}{|c|}{ Variabel } & $\begin{array}{c}\text { Nilai } \\
\text { aplha }\end{array}$ & Keterangan \\
\hline Finansial & 0,8807 & Reliabel \\
\hline $\begin{array}{l}\text { Lingkungan } \\
\text { kerja }\end{array}$ & 0,9526 & Reliabel \\
\hline Penghargaan & 0,8768 & Reliabel \\
\hline Kinerja & 0,8408 & Reliabel \\
\hline
\end{tabular}

Sumber : data diolah kembali, 2015 
Hasil pengujian reliabilitas dengan menggunakan seluruh variabel mempunyai nilai reliabilitas lebih dari 0,6 sehingga seluruh item dapat dikatakan reliabel.

\subsection{Deskripsi Data Penelitian}

Pengukuran yang dilakukan dalam penelitian ini didasarkan pada penyebaran kuesioner yang telah dilakukan secara langsung terhadap sampel atau responden yaitu semua pegawai pada Biro Kepegawaian Sekda Provinsi Kalimantan Selatan melalui Sample Random Sampling.

Dari hasil penelitian yang telah dilakukan pada objek penelitian yaitu staf pegawai negeri sipil Biro Kepegawaian Sekda Provinsi Kalimantan Selatan, melalui penyebaran angket pada responden (pegawai negeri sipil yang terpilih menjadi sampel penelitian, maka diperoleh hasil angket yang selanjutnya di sajikan pada tabel berikut :

Tabel 4.10

Distribusi Frekuensi Variabel Penelitian

\begin{tabular}{|l|c|}
\hline \multicolumn{1}{|c|}{ Variabel } & Rata-rata \\
\hline Finansial & 2,43 \\
\hline Lingkungan kerja & 2,31 \\
\hline Penghargaan & 2,34 \\
\hline Kinerja & 2,40 \\
\hline
\end{tabular}

Sumber : data diolah kembali, 2015

Secara perhitungan deskriptif dengan menggunakan nilai rata-rata diperoleh bahwa variabel finansial mempunyai nilai rata-rata yang lebih tinggi dibandingkan dengan variabel lainnya. Sedangkan variabel kinerja mempunyai nilai rata-rata 2,4

\subsection{Analisis Regresi Linier Berganda}

Dari hasil perhitungan statistik melalaui program SPSS versi 17.00, selanjutnya akan dilakukan analisis terhadap keberartian masing-masing koefisien Regresi.

Berikut disajikan rangkuman hasil perhitungan regresi linear berganda seperti tampak pada tabe berikut :
Tabel 4.11

Hasil Perhitungan Regresi Linier Berganda

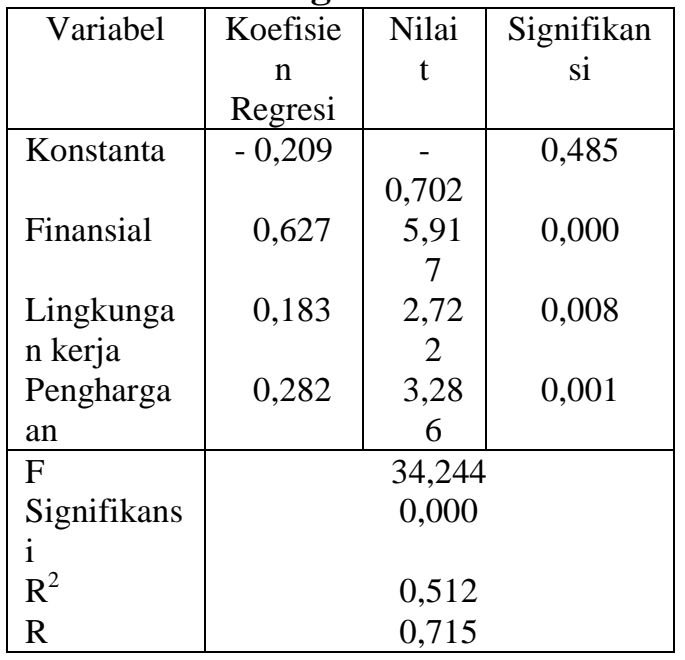

Sumber : data diolah kembali, 2015

\subsection{Pengujian Hipotesis}

\section{Pengaruh secara simultan/ bersama-sama}

Berdasarkan perhitungan di atas, maka langkah selanjutnya adalah melakukan uji hipotesis nyata (kebernyataan) model Regresi Linier dengan mengambil hipotesis:

Ho $=$ finansial $\left(X_{1}\right)$, Lingkungan Kerja $\left(\mathrm{X}_{2}\right)$, dan Penghargaan $\left(\mathrm{X}_{3}\right)$ secara bersama-sama tidak berpengaruh terhadap Kinerja Pegawai Biro Kepegawaian Sekda Provinsi Kalimantan Selatan (Y)

$\mathrm{Ha}=$ finansial $\left(\mathrm{X}_{1}\right)$, Lingkungan Kerja $\left(\mathrm{X}_{2}\right)$, dan Penghargaan $\left(\mathrm{X}_{3}\right)$ secara bersama-sama berpengaruh terhadap Kinerja Pegawai Biro Kepegawaian Sekda Provinsi Kalimantan Selatan (Y).

Dari perhitungan SPSS (seperti terlihat pada tabel ANOVA pada table 4.11), diperoleh nilai $F=34,244$ dengan signifikan 0,000 . Oleh karena signifikannya lebih kecil dari 0,05 maka Finansial $\left(\mathrm{X}_{1}\right)$, Lingkungan Kerja $\left(X_{2}\right)$ dan Penghargaan $\left(X_{3}\right)$ secara bersama-sama berpengaruh 
terhadap Kinerja Pegawai (Y) atau dengan kata lain Ha diterima dan Ho ditolak.

2. Pengaruh secara parsial Interpretasi :

a. Pengaruh variabel Finansial $\left(\mathrm{X}_{1}\right)$ terhadap Kinerja Pegawai (Y)

Berdasarkan perhitungan koefisien variabel Finansial $\left(\mathrm{X}_{1}\right)$ diperoleh nilai $\mathrm{t}=5,917$ dengan signifikan 0,000 . Oleh karena signifikannya lebih kecil dari 0,05:

Jadi terdapat pengaruh antara variabel Finansial terhadap Kinerja Pegawai.

Sedang dilihat besarnya koefisien regresi variabel finansial diperoleh nilai 0,627. Variabel finansial mempunyai koefisien regresi yang bertanda positif yang berarti apabila variabel finansial ditingkatkan, maka kinerja pegawai juga meningkat dengan koefisien sebesar 0,627 .

b. Pengaruh variabel

Lingkungan Kerja terhadap Kinerja Pegawai

Berdasarkan perhitungan koefisien variabel Lingkungan Kerja $\left(\mathrm{X}_{2}\right)$ SPSS diperoleh nilai $\mathrm{t}=2,722$ dengan signifikan 0,008. Oleh karena signifikannya lebih kecil dari 0,05 :

Jadi terdapat pengaruh antara variabel Lingkungan Kerja terhadap Kinerja Pegawai.

Sedang dilihat besarnya koefisien regresi variabel lingkungan kerja diperoleh nilai 0,183 . variabel finansial mempunyai koefisien regresi yang bertanda positif yang berarti apabila variabel lingkungan kerja ditingkatkan, maka kinerja pegawai juga meningkat dengan koefisien sebesar 0,183.

c. Pengaruh variabel

Penghargaan terhadap Kinerja Pegawai

Berdasarkan perhitungan koefisien variabel Penghargaan Kerja $\left(\mathrm{X}_{3}\right)$ SPSS diperoleh nilai $\mathrm{t}=3,286$ dengan signifikan 0,001 . Oleh karena signifikannya lebih kecil dari 0,05:

Jadi terdapat pengaruh antara variabel Penghargaan (X3) terhadap Kinerja Pegawai.

Sedang dilihat besarnya koefisien regresi variabel penghargaan diperoleh nilai 0,282. variabel finansial mempunyai koefisien regresi yang bertanda positif yang berarti apabila variabel penghargaan ditingkatkan, maka kinerja pegawai juga meningkat dengan koefisien sebesar 0,282

Hal ini sekaligus membuktikan bahwa nilai $t$ variabel finansial lebih tinggi dibandingkan nilai $\mathrm{t}$ dua variabel lainnya yaitu variabel lingkungan kerja dan variabel penghargaan. Dengan kata lain dapat disimpulkan bahwa variabel finansial paling dominan dalam mempengaruhi variabel Kinerja Pegawai, sehingga Ha diterima dan Ho ditolak.

\section{BAB 5}

PENUTUP

\subsection{Simpulan}

a. Secara bersama-sama/simultan variabel bebas dari motivasi melalu aspek (Finansial, Lingkungan Kerja, dan Penghargaan) mempunyai pengaruh yang signifikan 
terhadap variabel tergantung (Kinerja Pegawai). Dengan demikian, hipotesis I secara simultan variabel bebas faktor motivasi (Finansial, Lingkungan Kerja, Penghargaan) berpengaruh terhadap variabel Kinerja Pegawai dinyatakan dapat diterima.

b. Secara parsial, hasil perhitungan analisis regresi linier berganda terlihat bahwa pengaruh variabel Finansial merupakan faktor yang lebih dominan dalam mempengaruhi Kinerja Pegawai Biro Kepegawaian Sekretariat Daerah Provinsi Kalimantan Selatan.

\subsection{Saran}

a. Peningkatan terhadap kesejahteraan pegawai dalam bentuk finansial, baik langsung maupun tidak langsung kiranya menjadi agenda penting bagi jajaran pimpinan Biro Kepegawaian Sekretariat Daerah Provinsi Kalimantan Selatan dalam rangka pemeliharaan kinerja pegawai yang terkait dengan kondisi ekonomi saat ini. Hal ini bisa dikaitkan dengan reward yang akan diberikan kepada para pegawai yang telah menunjukkan kinerja yang meningkat.

b. Pembayaran sebagai uang Tunjangan Hari Tua (THT/Pensiun) di depan, perlu dipertimbangkan. Mengingat, bahwa kebijakan ini akan membuat pegawai dapat membangun masa depannya dengan lebih baik, karena pemanfaatan uang THT dirasakan saat masih aktif bekerja, sehingga perencanaan masa depan pegawai dapat dilakukan dengan lebih matang.

c. Perlindungan ekonomis terhadap bahaya, di samping asuransi, serta beberapa benefit dapat meningkatkan jaminan keamanan guna melindungi penghasilan pegawai sebelum dan sesudah pensiun, yang dapat berupa: jaminan pembayaran dalam jumlah tertentu selama suatu periode, serta tunjangan pengobatan yang lebih disesuaikan dengan kondisi saat ini.

\section{DAFTAR PUSTAKA}

Arep, Ishak dan Hendri Tanjung. 2003. Manajemen dan Motivasi. Jakarta: Grasindo.

As'ad Moh. 1991. Psikologi Industri. Yogyakarta: Liberty.

Gibson, James L., Ivancevich, John M., and Donelly JR, James H. 1998. Organisasi: Perilaku, Struktur, Proses. (Alih Bahasa: Nunuk Adiarni), Edisi Kedelapan. Jakarta: Binarupa Aksara.

Hedjrahman dan Suad Husnan. 2003. Manajemen Personalia. Edisi Keempat, Yogyakarta: BPFE.

Handoko, T. Hani. 1986. Manajemen Personalia dan Sumber Daya Manusia. Edisi Kedua. Yogyakarta: BPFE.

Koontz, Harald and Winhrich Heinz. 1990. Essential of Management. Singapura: Mc Graw Hill International.

Malhotra, N.K. 1996. Marketing Research. London: Prentice-Hall Internasional Inc.

Masrun. 1979. Analisis Item. Yogyakarta: Fakultas Psikologi UGM.

Prawirosentono Suryadi. 1999. Kebijakan Kinerja Karyawan. Edisi Pertama. Yogyakarta: BPFE. 
Robbins, Stephen P. 1997. Perilaku Organisasi Konsep, Kontroversi. Aplikasi. Edisi Kedelapan (Alih Bahasa: Hadyana Pujaatmaka dan Benyamin Molan; Editor: Agus Widyantoro). Jakarta: Prenhallindo.

Schemerchon, John, Hunt, Osbora. 1994. Managing Organizational Behaviour. New York: Graw Hill Internasional.

Simamora, Henry. 1997. Manajemen Sumber Daya Manusia. Edisi Kedua. Yogyakarta: Sekolah Tinggi Ilmu Ekonomi YKPN.

Singarimbun, Masri dan Sofian Effendi. 1987. Metode Penelitian Survei. Jakarta: LP3ES.

Soehartono, Irawan. 2000. Metode Penelitian Sosial. Cetakan Keempat. Bandung: Remaja Rosdakarya.

Soekarwo. 2004. Peningkatan Kinerja Birokrasi. Buletin Prasetya, nomor 3: 3033.

Sugiyono. 2003. Metode Penelitian Bisnis. Bandung: Alfabeta

Suprihanto, John. 1988. Penelitian Kinerja Karyawan. Edisi Pertama. Yogyakarta: BPFE.

Triguno. 1997. Budaya Kerja. Jakarta: Golden Tenayon Press.

Zainuddin, Muhammad. 2000. Metode Penelitian. Tidak dipublikasikan 